\title{
THE CALIFORNIA LEGISLATIVE APPROACH TO PROBLEMS OF WILLFUL CHILD ABUSE
}

Public concern over the problem of willful child abuse is reflected by recent legislation, enacted in over thirty states, requiring physicians and others in related professions to report child abuse cases. ${ }^{1}$ Legislative concern in Cahifornia during 1965 and 1966 resulted in changes to both the mandatory reporting laws ${ }^{2}$ and the special criminal statute applicable to child abuse cases. ${ }^{3}$ The California legislation provides the focal point for this Comment. Lawyers are confronted with new statutory requirements in both advising physicians and others covered by the mandatory reporting laws, and in evaluating possible hability under the new Cahfornia criminal child abuse statute.

While many children are deprived of sufficient food, clothing, shelter and parental guidance, discussion here is restricted to a consideration of willful child abuse. Excluded are the whole range of injuries and deprivations caused by involuntary neglect, poverty, and necessitous circumstances, since problems resulting from willful abuse appear significantly different from those stemming from simple neglect. The type of abuse discussed in this Comment is not restricted to the classic case of the "battered child" but includes other cases of abuse and neglect provided that the element of willfulness is present. Part I of this Comment discusses generally the nature of the problem and considers the diffculties in discovering incidents of child abuse. Part II deals with developments in California statutory law requiring physicans and others to report suspected cases of child abuse to public authorities; and part III considers the penal law applicable to child abusers. The present method employed in California to handle child abuse cases, with possible alternatives and variations, is discussed in part IV.

\section{I}

NATURE OF CHILD ABUSE

There is some degree of consensus on certain general conclusions among those with experience in the field of child abuse. ${ }^{5}$ Child abuse

1 McCoid, The Battered Child and Other Assaults Upon the Family: Part One, 50 MINN. L. REv. 1, 20 (1965). Reporting legislation throughout the United States is thoroughly discussed in McCoid, supra at 19-58.

2 CaI. Pen. Cone $\S \S 11110,11161.5$. These sections deal specifically with reporting of child abuse cases. Other California statutes require reporting by physicians and those in related professions of cases involving injuries inflicted in violation of any penal law. CaL. PEN. CODE $\$ \S 11160,11161,11162$.

3 Caz. Pen. Code § 273a.

"The term "battered child" was coined in Kempe, Silverman, Steele, Droegemueller \& Silver, The Battered-Child Syndrome, 181 J.A.M.A. 17 (1962).

5 For a comprehensive collection and discussion of the articles in social welfare and 
cases often involve serious injuries or death, ${ }^{6}$ and in many cases the episodes of abuse are repetitive. ${ }^{7}$ Abused children are usually very young $;^{8}$ one study reported that the peak incidence of abuse occurred at three months of age. ${ }^{9}$ Ordinarily only one child in a family is singled out for abuse. ${ }^{10}$ Child abuse does not appear to be correlated with either race, cultural background, or religion, nor is it restricted to families with low income. ${ }^{11}$ The number of child abuse cases is not known ${ }^{12}$ since most cases do not come to the attention of anyone other than the iminediate family. ${ }^{13}$

medical journals about child abuse, see McCoid, supra note 1, at 3-19. Kempe, supra note 4, is, according to McCoid, the landmark discussion in this area.

6 Kempe, supra note 4 , at 17 reported a nationwide study which indicates the serious nature of those cases which do come to the attention of hospitals and district attorneys. Seventy-one hospitals reported 302 cases in a one-year period in which 33 children died and 85 suffered permanent brain injury. In a one-year period 447 cases were reported by district attorneys, with 45 children dying as a result of their injuries and 29 suffering permanent brain damage.

7 Bryant, Billingsley, Kerry, Leefman, Merrill, Senecal \& Walsh, Physical Abuse of Children-An Agency Study, 42 Cinc Welfare 125, 129 (1963); see Boardman, A Project to Rescue Children from Inflicted Injuries, Social Work, Jan. 1962, pp. 43, 44; Gwinn, Lewin \& Peterson, Roentgenographic Manifestations of Unstspected Tranma in Infancy, 176 J.A.M.A. 926, 927 (1961); Kempe, supra note 4, at 22.

8 Gwinn, supra note 7, at 927 . Gwinn reports that most of the patients are less than two years old; the majority are less than one year old. A study reported by Vincent De Francis, Director of the Children's Division of the American Humane Association, analyzing newspaper reports of child abuse cases nationwide, found that only $10 \%$ of the abused children were ten years old and a majority were under age four. Of the children who died, over $80 \%$ were less than four years old and a majority were under two years old. The study extended over the year 1962 and is summarized in McCoid, supra note 1, at 15 .

9 McHenry, Girdany \& Elmer, Unsuspected Trauma with Multiple Skeletal Injuries During Infancy and Childhood, 31 Pediatrics 903, 906 (1963). Fifty children admitted to Children's Hospital at Pittsburgh, Pennsylvania with multiple skeletal injuries were studied. Of these fifty cases, twenty-two case histories of trauma were obtained, and all but five of these involved an infliction of injury, usually by the parents. Sixty-seven per cent of the children were less than mine months old, and $12 \%$ were between nine and fifteen months old. Three months of age represented the peak incidence of abuse, and the number of injuries fell off sharply in the age groups over three months. Compare this with the distribution of childhood accidents with reference to age, where the peak is reached at two years, and the curve falls off slowly after that. Ibid.

10 Boardman, supra note 7, at 45; Bryant, supre note 7, at 129; FontaNa, THE MaItreated Child: The Maltreatalent Syndrome In Chindren 18 (1964); but see Kempe, supra note 4, at 18-19. According to Boardman, hospital staff members believe that because only one child in the family is abused the child has become a symbol of some kind to the adult, and the adult's controls are so tenuous that periodically his anger explodes against the symbol.

11 Boardman, supra note 7, at 44 . Kempe, supra note 4, at 24 remarks that abuse is not confined to parents with psychopathic or sociopathic personahities or in low socio-economic groups, but that most reported cases fall within these categories.

12 Report of the Assembly Internat Conm. on Crmmnal Procfoure 68, 73 (1965) [hereinafter cited as Assemand REPORT].

13 Id. at 70. 


\section{A. Psychological Characteristics of Parents}

Most of the observations concerning the psychological nature of child beaters are reported by physicians and social workers in medical and social welfare journals. One study classified child abusers into three psychological groups. ${ }^{14}$ One type is passive, dependent, and immature. The second group was described as hostile and aggressive-continually angry. The study indicated that these visible signs of psychological imbalance stem from a conflict within the parent, and external difficulties which normal people take in stride stimulate a direct expression of anger finding its outlet in physical violence upon the child. ${ }^{15}$ The third group was characterized by compulsiveness, rigidity, and a lack of warmth. Perhaps abuse in the latter class inay be traced to a lack of understanding of the nature of young children and an attempt to force an overly rigid discipline upon them. On the basis of personal experience and contact with doctors, police, and juvenile court probation officers, an observer at the Los Angeles Children's Hospital described child beaters as either unstable or immature emotionally, or so egocentric that to them the child is a handicap in hiving their own hives. ${ }^{16}$

Statements concerming the psychological make-up of child abusers are tentative and speculative. The causes of psychological characteristics noted in abusive parents are unknown, although it has been suggested that at least some abusive parents had themselves been abused as children. ${ }^{17}$ In short, hittle more than superficial facts are known about those adults who inflict injuries upon their children. ${ }^{18}$

\section{B. Problems of Discovering Child Abuse Cases}

At least two of the problems of discovering cases of child abuse are obvious: The victims are generally too young to report the matter; and there are seldom witnesses to the abuse except the immediate family.

To justify either court action or a program of social casework with the family, it is generally necessary to have a reasonably accurate medical diagnosis of the case as one caused by externally inflicted violence. ${ }^{19}$

14 Bryant, supra note 7, at 127-28. The study also included a fourth category of physically disabled fathers whose families were supported by the wife. These fathers, frustrated since they were no longer the providers, maintained rigid discipline with swift, severe punishment.

16 Id. at 128.

16 Boardman, supra note 7 , at 47. Miss Boardman is director of social services at Los Angeles Children's Hospital.

17 Fontana, supra note 10, at 18-19; Kempe, supra note 4, at 18.

18 Boardman, supra note 7, at 44-45; FonTaNA, op. cit. supra note 10, at 19; see Kempe, supra note 4, at 18.

19 Interview with Eugene E. Brott, Deputy District Attorney, Alameda County, California, Nov. 17, 1965. Mr. Brott stated that cooperation of doctors who had diagnosed the case is essential to a successful prosecution of the parents, and that juvenile court 
Diagnosing a child abuse case involves an analysis of three main cal language) is hampered first of all by the inexperience of most doctors with these cases. Any one physician in private practice may not encounter a sufficient number of cases to recognize the symptoms of child abuse. ${ }^{20}$ Many doctors are so shocked at the thought that the injuries were inflicted by the parents that they consciously refuse to consider abuse as a possible cause. ${ }^{21}$ The parents almost never admit that the child has been abused, but claim the child has a "bruising tendency," make up a story to explain the injuries, or profess not to know how the injuries occurred. The adults involved invariably protect each other. ${ }^{22}$ In short, if the doctor can overcome his own inexperience with child abuse cases and his natural reluctance to consider abuse as a cause of the injuries, he may be hampered by the parents' misleading explanations.

Diagnosis of child abuse cases (willful or unsuspected trauma in meditypes of evidence. First, the clinical symptoms may arouse the physician's suspicion, although it is frequently difficult to decide on clinical grounds alone whether the injuries resulted from abuse. ${ }^{23}$ Often the general health of the infants is poor; they frequently are pale and poorly nourished. ${ }^{24}$ The child may have bruises, abrasions, and lacerations. Subdural hematoma (hemorrhaging of the brain) and ruptured internal organs may be present. ${ }^{25}$

The second type of evidence is based on statements by the parents. Their fabricated version of how the injuries occurred aids diagnosis of the case as one of child abuse when the parental explanation simply can-

action is generally not taken unless the evidence is sufficient to justify a criminal prosecution. The physician's testimony may be extremely important in establishing even the corpus delicti of the crime. In liams v. Superior Court, $236 \mathrm{Cal}$. App. 2d 80, $45 \mathrm{Cal}$. Rptr. 627 (1965), the only admissible evidence to show at the preliminary hearing that the injuries were intentional was the physician's diagnosis, since extrajudicial statements of the accused were inadmissible until the corpus delicti had been establishcd. Due to the nature of the injuries, the doctor was unable to diagnose the case as one of probable intentional abuse, and consequently the information had to be set aside. Sometimes, however, the fact of abuse or neglect is so apparent that medical opinion is not needed. A case of extreme child neglect is reported in People v. Harris, 239 A.C.A. 415, 48 Cal. Rptr. 677 (1966). The situation was reported to the police by a neighbor, and no expert testimony was needed to prove, in a prosecution against the parent, that a criminal conviction for willful violation of the child abuse statute was warranted by the evidence.

20 Gwinn, supra note 7, at 926; see FonTANA, op. cit. supre note 10, at 5.

21 Bain, The Physically Abused Child, 31 Pedtatrics 895, 896 (1963); Kempe, sutpra note 4, at 18-19; see Snedeker, Traumatization of Children, 267 NEw ENGL. J. MED. 572 (1962).

\footnotetext{
22 Boardman, supra note 7, at 45 .

23 Gwinn, supra note 7, at 929.

24 Id. at 927; Kempe, supra note 4, at 17-18.

25 Gwinn, supra note 7, at 927 .
} 
not account for the nature of the injuries. ${ }^{26}$ The theory, often insisted upon by the parents, that a "bruising tendency" of the child is responsible for the injuries, may be rebutted if no further injuries are sustained while the child stays in a hospital. Adroit questioning of the parents will sometimes elicit the information that the child has been attacked by his parent. ${ }^{27}$

The third main type of evidence in diagnosing a suspected child abuse case is an X-ray analysis of the child. ${ }^{28}$ Serious cases of abuse often involve twisting or jerking the child's hmbs with consequent bone injury. ${ }^{20}$ Full skeletal $\mathrm{X}$ rays will show whether there are several bone injuries in various stages of healing. Since a major characteristic of abuse is its repetitive nature, positive results with the $\mathrm{X}$ rays strongly indicate that the injuries were inflicted upon the child. ${ }^{30}$

\section{II}

TRANSMISSION OF THE CASE FROM THE PHYSICIAN

TO PUBLIC AUTHORITIES: THE ROLE OF REPORTING STATUTES

It is extremely important that cases of suspected child abuse be brought to the attention of public authorities as early as possible. Because inflicted injuries are often serious and coupled with a pattern of abuse, these children must be considered in danger so long as they are with their parents and there is no intervention by public authorities. Althougl doctors and hospitals are in the best position to discover cases

26 See Fontana, op. cit. supra note 10, at 16; Kempe, supra note 4, at 18.

27 See Kempe, supra note 4, at 19.

28 Boardman, supra note 7 , at 46 , raises the problem confronting a physician in private practice who suspects a case is one of abuse, wants to take skeletal $X$ rays of the child, and also wants to be compensated for doing so. The problem stems from practical difficulties in making a contract with the parents to pay for the $X$ rays without alerting them to the physician's suspicion. Generally liability for medical services rests upon contract. McClenahan v. Keyes, 188 Cal. 574, 206 Pac. 454 (1922); McClenahan v. Howard, 50 Cal. App. 309, 195 Pac. 68 (1920). However, a physician could probably recover under a theory based on $\S 196$ of the California Civil Code, which provides that the parent entitled to the custody of a child must give him support and education suitable to his circumstances. Since medical services rendered to the child come within section 196, a parent may be obligated to pay for the value of these services even without an express contract to do so. See Slaughter v. Zimman, 105 Cal. App. 2d 623, 234 P.2d 94 (1951); Toney v. Security First Nat'l Bank, 108 Cal. App. 2d 161, 238 P.2d 645 (1951). It seems that an accurate diagnosis of the cause of a child's injuries would be a proper medical service, and skeletal $X$ rays are simply an effective tool of diagnosis. However, the doctrine is limited by its quantum meruit basis, in that the services must have been beneficial to the child, and by $\$ 196$ since under that provision a parent need not provide unnecessary medical services to his child.

20 Gwinn, supra note 7, at 927.

30 Ibid; Kempe, supra note 4, at 23. 
of child abuse, ${ }^{31}$ referrals by them do not constitute a large source of information to public authorities. ${ }^{32}$ The reasons for reluctance of physicians to report are not hard to find. In some cases of suspected child abuse the medical diagnosis is not entirely clear, the story given by the parent may be sufficiently plausible, and reporting a case involves the parents with the police. Physicians may feel that the ethical confidential relationship with a patient precludes reporting, but since the patient here is the child, reporting should rather be in furtherance of the physician's obligation to his patient. ${ }^{33}$ In a few cases the reason for the physician's failure to report is the absence of any recognition on his part that he has a social responsibility to do so. ${ }^{34}$

One factor discouraging the reporting of suspected child abuse cases in California prior to 1965 was a fear of possible civil suit against the reporting physician. ${ }^{35}$ Until that year there was no explicit statutory immunity for reporting cases of suspected child abuse. Such a suit would have been for malicious prosecution, libel, or slander, but the chances of succeeding were small. ${ }^{36}$ Nevertheless, it is strongly suspected that fear of civil suit deterred many physicians from reporting abuse cases.

California was the first state to enact legislation requiring doctors to report suspected cases of child abuse. ${ }^{37}$ This legislation was not en-

\footnotetext{
31 Assearbey Report at 71; De Francts, Gumelnnes for Legtstation to Protect the BATTEREd CEIID 6 (1962).

32 The study reported by Bryant, supra note 7, involved 115 families with 180 seriously abused children who had been reported to the Massachusetts Society for the Prevention of Cruelty to Children. Neighbors, legal authorities, and relatives reported respectively 22\%, $23 \%$, and $24 \%$ of the cases. Although physicians had seen about $30 \%$ of the cases involved, they reported only $9 \%$. Id. at 126-2\%.

33 See McCoid, supra note 1 , at 32-35.

34 Bain, supra note 21 , at 896 .

35 Assearbly REPORT at 72 ; see Snedeker, supra note 21. The Cahifornia mandatory reporting law, CAL. PEN. CODE $\$ 11161.5$, as amended in 1965, confers immunity from any civil or criminal liability as a result of making a report authorized by the section.

36 See notes 53-57 infra and accompanying text. McCoid, supra note 1, at 37-38 suggests that other possible bases for recovery could be invasion of privacy by disclosing private facts or placing the parents in a false light, or breach of confidence. "Yet every reported American case in which a physician has made disclosures concerning patients for the protection of third parties has resulted in recognition of a privilege on the part of the physician and a denial of hability. There seems bittle doubt that where the physician or hospital makes disclosures which are beneficial to the child patient or which may prevent future abuse of this child or others, the courts will recognize at least a quahified privilege which can be overcome only by a showing of matice or lack of good faith belief in the facts reported." Id. at 38-39. It is extremely unlikely that any invasion of privacy suit could be based on the mere reporting of suspected child abuse cases by a physician to public authorities. The relevant types of invasion of privacy, public disclosure of private facts and placing plaintiff in a false light, require publicity. See Prosser, ToRTs 835, 837 (3d ed. 1964).

37 See Harper, The Physician, The Battered Child, And The Law, 31 Pedutrics 899, 900 (1963).
} 
tirely successful, perhaps because the physicians' reluctance to report remained strong. Also, the complete dearth of appellate cases probably indicates that the statutes were not enthusiastically enforced.

\section{A. Pre-1965 California Reporting Statutes}

\section{The General Reporting Sections}

Califorma Penal Code section 11160, enacted in 1953, required hospitals and pharmacies to immediately report any incident in which a person came or was brought to them suffering from an injury inflicted in violation of any penal law of California. The report was to be made both by telephone and in writing to specified law enforcement officers. Section 11161 made the requirements of section 11160 applicable to physicians who had such an injured person under their charge or care. The name of the injured person, his location, and the character and extent of his injuries were to be included in the report. Section 11162 classified violation of the above provisions as a misdemeanor, and provided for punishment not exceeding a 500 dollar fine and six months in jail.

Although these statutes did not relate specifically to cases of child abuse, they included cases "where injuries have been inflicted upon any person in violation of any penal law of this state."38 Cahifornia Penal Code section $273 \mathrm{a}^{39}$ (until 1965) ${ }^{40}$ prohibited the willful infliction of unjustifiable pain or mental suffering upon a child, the willful causing or permitting a child to be placed in a situation where its life or limb might be endangered or its health likely to be imjured, and, in the case of a custodian of a child, the causing or permitting the child's bife or $\mathrm{hmb}$ to be endangered or his health injured. It seems clear that sections 11160,11161 , and 273a together required reporting by physicians and hospitals of child abuse cases, although there was conceivably a problem since a doctor or hospital could not be certain that the injuries had been inflicted in violation of section 273a. Available authority indicates, however, that the legislative intent was to require a report where the physician, hospital, or pharmacy had probable cause to believe that the injury was the result of the violation of a penal provision. ${ }^{41}$

It is not clear whether all violations of section 273a fell within the reporting requirements of sections 11160 and 11161. Since section 11160 requires reporting when "injuries have been inflicted upon any person," it is doubtful that a physician would have to report a violation of section

38 Cat. Pen. Code $\$ 11160$.

39 See note 61 , infra, for the pre-1965 form of $\S 273 a$ of the California Penal Code.

40 See note 76, infra, for the present form of California Penal Code $\$ 273$ a. The 1965 amendments introduced little substantive change.

4136 Ops. Cat. ATr'y Gen. 200 (1960). 
273a where the offense consisted solely of causing or permitting the child's life or himb to be endangered.

Unless the word "injuries" in sections 11160 and 11161 is construed to include "mental suffering" as used in section 273a, the doctor would not be required to report such a case.

It seems advisable for Cahifornia courts to include mental suffering as an injury under sections 11160 and 11161 since inexcusable failures to report cases of mental suffering may arise and the other reporting statutes require physical injury. Counterarguments are that the legislative intent in section 11161.5 , the 1963 addition to the reporting statutes which requires physical injury, sliould be applicable to sections 11160 and 11161, and that the difficulties of diagnosing a case of intentional infliction of mental suffering are too great to justify criminal sanctions for failure to report it.

\section{The 1963 Addition to California Reporting Statutes: Section 11161.5}

California Penal Code section 11161.5, enacted in 1963, provided that any doctor to whom a minor was brouglit for diagnosis or treatment, or who had a minor under his charge or care, was to report to law enforcement agencies, or to the nearest child welfare agency offering child protective services, if it appeared to the physician that the child might have been a victim of a violation of section 273a. Content of the report was the same as under the other statutes. This part of section 11161.5 differed from sections 11160 and 11161 because (1) it appeared to require reporting when the doctor had something less than probable cause to suspect that the case was one of child abuse, and (2) it appeared to require reporting even where the suspected violation of $273 \mathrm{a}$ consisted of inflicting unjustifiable mental suffering upon the child or endangering him. However, the second paragraph of section 11161.5 stated that the physician was not required "to report as provided lierein if in his opinion it would not be consistent with the health, care, or treatment of the minor." The scope of this exempting clause is not clear, but it certainly diluted the physician's duty to report violations of section 273a. Undoubtedly it would excuse any failure to report under section 11161.5 if the physician had any plausible basis for his opinion that reporting would be inconsistent with the health, care, or treatment of the minor. Only an extremely serious case of child abuse, coupled with a lack of reasons for not reporting, miglit have subjected a physician to prosecution for failure to report under section 11161.5.

Section 11161.5 may have preempted the general reporting sections, 
11160 and 11161, in the area of section 273a violations. ${ }^{42}$ On the other hand, section 11161.5 may have apphed, to the exclusion of the general reporting sections, to only those cases which did not fall within the general sections. Consequently if the doctor had less than probable cause to suspect child abuse, section 11161.5 alone would be apphicable; if he did have probable cause to believe the child's injuries were inflicted in violation of section 273a, perhaps the general reporting sections still applied. If the suspected violation of section 273a was infliction of mental suffering, section 11161.5 would apply; if physical injuries (or mental suffering, assuming sections 11160 and 11161 encompass it) were involved, sections 11160 and 11161 would still apply. The question of whether section 11161.5 preempted the general sections, or simply added a much weaker reporting requirement for violations of section 273a not covered by the general sections, was never decided and was mooted by the 1965 amendment to section 11161.5.

\section{B. The 1966 California Reporting Statute}

\section{Substantive Reporting Requirements}

Cahifornia Penal Code section 11161.5, as amended in 1965 and 1966, provides that where a minor is brought to a physician or other specified person ${ }^{43}$ for diagnosis, examination, or treatment, or is under his charge or care, and it appears to the physician that the minor has physical imjury or injuries which appear to have been inflicted upon him by other than accidental means by any person, he shall report this fact by telephone and in writing to the head of the police department, sheriff, or district attorney. The required content of the report is the same as under section 11160 and pre-amendment section 11161.5-if known, the name of the minor, his location, and the character and extent of his injuries. Since the 1965 amendment, section 11161.5 no longer contains a clause exempting a physician from the duty to report if in his opinion it would be inconsistent with the health, care, or treatment of the minor, and the statute should be fully operative when a case falls within its terms.

The inportant question is under what circumstances reporting is

42 See 38 CAL. S.B.J. 762 (1963), concluding that $\$ 11161.5$ probably exempted $\S 273 \mathrm{a}$ cases from $\$ \S 11160$ and 11161.

43 The 1965 amendments included physicians, surgeons, dentists, residents, interns, chiropractors, and religious practitioners in the class required to report. The only change in 1966 extended the provision to include directors of county welfare departments, and superintendents and principals of public or private schools. Since most children subjected to serious willful physical injury are of pre-school age (see notes 8 and 9 supra) the 1966 amendment will do little to aid discovery of these cases. However, school officials and county welfare directors may observe cases of neglect that would probably never come to the attention of a physician. 
required in California. The answer depends upon the substantive requirements of the statutes and the extent to which the newly-enacted section 11161.5 has removed child abuse cases from the operation of sections 11160 and 11161. A physician (and other persons covered by section 11161.5) must report when (1) a minor is brouglit to the plyysician and it appears to him that the minor has pliysical injuries, and (2) it appears to the plysician that the injuries were inflicted upon the child by other than accidental means.

Section 11161.5 may be interpreted as imposing one of two standards. Perliaps a physician is liable for failing to report if it slould have appeared to him that the injuries were inflicted upon the child; this is an objective standard. But probably the more reasonable interpretation of the statutory language is that no physician can be convicted unless it is shown that it actually appeared to him that the injuries were inflicted upon the child. The latter, a subjective standard, would make obtaining convictions difficult.

Any answer to the question of when reporting is required also depends upon the extent to which section 11161.5 has preempted sections 11160 and 11161 . Since sections 11160 and 11161.5 do not require reportimg by the same persons, any argument that section 11161.5 has preempted section 11160 in child abuse cases, because it applies only to child abuse and is the more recent statute, would be untenable. Section 11160 applies to (1) every person, firm, or corporation conducting a hospital or pharmacy in Califorma, (2) the managing agent or person in cliarge of any of those institutions, and (3) the person in charge of a hospital ward. The above persons are required to report whenever they have probable cause to believe a person coming to the pharmacy, hospital, or ward has injuries inflicted in violation of any penal law including section 273a. Section 11161.5 applies to physicians, surgeons, residents, interns, chiropractors, religious practitioners, school superintendents and principals, and county welfare directors. Unless section 11160 still applies to those persons named in it, they will escape any liability for even the most irresponsible failures to report. It seems that the person in charge of a ward in a hospital, who has probable cause to believe that mjuries to a child in his ward resulted from abuse, is equally at fault with the intern who is caring for the child. Since sections 11160 and 11161.5 do not conflict, both should be applied according to their terms.

A closer question is whether section 11161, which makes the requirements of section 11160 applicable to physicians and surgeons, has been superseded by section 11161.5. One argument is that section 11161.5 also applies to plyysicians and surgeons, it is more recent, and it is the 
only statute applying specifically to child abuse cases. Therefore, one should infer a legislative intent that section 11161.5 alone should apply where persons covered by it are involved in a child abuse case. The counter-argument is that section 11161.5 is merely an addition to the general reporting sections and that no preemption was intended. Arguably, there is nothing wrong with having two sections under which to prosecute a physician or surgeon for failing to report. In addition, perhaps the statutes do not duphicate each other in all respects. If the word "injuries" in sections 11160 and 11161 includes mental suffering, then a physician could be prosecuted under those sections because the willful infliction of mental suffering upon a child violates section 273a, and reports are required under sections 11160 and 11161 whenever the physician has probable cause to believe the "injuries" were inflicted in violation of a penal law. But since section 11161.5 requires "physical injury or injuries," no one would be liable under that section for failing to report a child abuse case involving only mental suffering. Of course, if "injuries" in the general reporting sections means only "physical injuries," this argument loses all force.

A third argument that sections 11160 and 11161 still apply to child abuse cases is based upon the discrepancy between those sections and section 11161.5 as to the degree of certainty a physician must have in suspecting that a child has been abused. This argument rests upon the theory that some cases might be prosecuted under the general sections that could not be prosecuted under section 11161.5. Whether the argument has force depends upon the interpretation given section 11161.5. If section 11161.5 imposes an objective standard-a physician must report whenever it should have appeared to him that the child's injuries resulted from abuse-then section 11161.5 requires a report at least in every case where probable cause exists to require a report under the general sections, and the argument that the general sections still apply would fall. However, section 11161.5 probably imposes a subjective standard-no physician is required to report unless it actually appears to him that the child's injuries resulted from abuse. Under such a standard a physician might not be hable under section 11161.5 even though the evidence justifies a finding of probable cause under sections 11160 and 11161. To secure reporting of the maximum number of cases, the general sections should be regarded as fully applicable, and section 11161.5 should be considered as only an addition to them.

It is difficult to say definitely when the legal duty to report arises. Where a person covered by section 11160 (hospitals, pharmacies, their managing agents, and the head of a ward to which an injured child is brought) has probable cause to beheve injuries of the child brought to 
him resulted from willful abuse, he should report since section 11160 has probably not been preempted. If it appears to a physician (or others covered by section 11161.5) that physical injuries of a child under his care were inflicted, reporting is required. It is unclear if liability will result for failure to report a case involving only mental suffering; if hability is imposed, only those persons named in section 11160 and physicians and surgeons under section 11161 (unless section 11161.5 has preempted section 11161) will be covered. It is also unclear whether a physician denying that it appeared to him that a child's injuries were inflicted could be convicted under section 11161.5 on the theory that it should have appeared to lim that the injuries were inflicted. In such a situation, if section 11161.5 embodies a subjective standard, and this seems to be the most reasonable reading of its language, then liability could be imposed under sections 11160 and 11161 where there was probable cause. A prudent physician would report whenever he thinks the child's injuries did not result from accidental means; even if he might escape liability under section 11161.5 by saying he thought the injuries happened accidentally, he still might be prosecuted under the general sections if he had probable cause to believe the injuries resulted from abuse.

Difficulty in ascertaining exactly when reports are required in California is caused by both the vague standards in section 11161.5 and the lack of clear legislative intent concerning the role of sections 11160 and 11161. Clarity in these reporting statutes could be achieved by including all requirements for reporting child abuse cases in a single exclusive section, and clearly defining the persons who have a duty to report and the cases which must be reported.

\section{Licensing Revocation or Suspension: A Possible Method of Enforcing the Reporting Statutes}

Aside from confusion about the substantive requirements of the reporting laws, there is some doubt whether the criminal sanctions chosen are appropriate.

Perhaps the reporting laws could be more effectively implemented by a procedure for revoking or suspending a physician's license to practice. The Board of Medical Examiners is now required to take action against any physician who is guilty of unprofessional conduct which has been brought to the attention of the Board. ${ }^{44}$ The definition of unprofessional conduct includes, but is not limited to, gross negligence, immorality, and incompetence, and the commission of any act involving

44 Cax. Bus. \& Prof. Code § 2361. 
moral turpitude, dishonesty, or corruption. ${ }^{45}$ The Board is authorized to disciphne any physician it finds guilty of unprofessional conduct. Sanctions include suspending or revoking the physician's license. ${ }^{46}$ If it is felt that a physician would be more likely to report when faced with the possible loss of his license than by the remote threat of a criminal prosecution, the definition of "unprofessional conduct" could be explicitly clarified to include inexcusable failure to report suspected cases of child abuse. ${ }^{47}$ The effectiveness of the present sanctions (a misdenneanor prosecution alone) should be tested before the suggested alternative of revoking licenses of offending plyysicians is seriously considered. A greater degree of knowledge on the part of physicians about the existence of the child abuse problem, ${ }^{48}$ and an appreciation of the physician's role in bringing these cases to light will probably result in increased reporting irrespective of existing sanctions against the physician for not reporting.

\section{The Central Registry for Child Abuse Reports}

The 1965 amendment to the California Penal Code sections relating to child abuse also introduced a central registry for recording reports of suspected cases of child abuse. Section 11161.5 provides that copies of all written reports received by a law enforcement agency shall be forwarded to the State Bureau of Criminal Identification and Investigation. By Califormia Penal Code section 11110, the Bureau is required to maintain records of all these reports. Upon receipt of a report from a law enforcement agency, the Bureau is to inform the agency of all previous abuse reports and arrests or convictions for violation of section 273a concerning the same minor or other minor in the same family. This information is available to any physician, probation department, or child protective agency.

The central registry should be extremely valuable in diagnosing cases of child abuse. Because of fear of legal consequences, parents do not usually return with the injured child to the same doctor or hospital. ${ }^{49}$

45 Ibid.

46 CaI. Bus. \& Prof. Code § 2372.

47 It is arguable that reporting suspected child abuse cases is a physician's professional obligation. In A.M.A., PrnNCrPles of Medical Ermics \& 9 (1957) (reprinted in McCoid, supra note 1 , at 32-33) it is stated that "a physician may not reveal the confidences entrustcd to him in the course of medical attendance, or the deficiencies he may observe in the character of patients, unless he is required to do so by law or . . . unless it becomes nccessary in order to protect the welfare of the individual or of the commumity." By negative inference a physician slould report when he is required by law to do so or if it is necessary to protect the welfare of the child.

48 Information about child abuse is being disseminated at an increasing rate among the medical profession. See articles cited in McCoid, supra note 1, at 3-19.

49 Assembly RePORT at 73. 
Reports that a child has previously been a victim of suspected abuse are a good indication that the present case is one of abuse, and that the child may be in extreme danger if left with his parents. Since a decision to remove the child from the parents' custody is serious, the knowledge that the child has previously been a victim of abuse puts a court in a much better position to evaluate the probability of danger to the child in remaining with his parents.

\section{Immunity from Suit Under the Reporting Statute}

Under the new reporting law, section 11161.5, no physician incurs any civil or criminal liability as a result of making any report "authorized by this section." Presumably a report not authorized by section 11161.5 would not be entitled to the statutory immunity. A literal approach would treat a report as authorized only if such a report is required by the section. A report would be unauthorized if it contained information not required by the statute, or if the physician did not have the requisite state of mind to trigger the reporting requirement. Under an approach looking to the purpose of the statute, reports would be deemed authorized if they contained information which, though not required, would aid the objectives of detecting abuse cases and preventing further harm to the children involved. This approach could classify as unauthorized those reports made by a physician who neither believed nor had reasonable grounds for believing the case to be one of abuse, since reporting under those circumstances would not further the statute's purpose.

The literal approach results in a more limited class of authorized reports, and thus creates a number of exceptions to the immunity clause. The first exception is based upon the required content of the reports. Section 11161.5 says that when a minor is brought to a physician, and it appears to the physician that the minor has physical injuries which appear to have been inflicted by other than accidental means, he shall report "such fact." The next: sentence of the statute requires that the report state, if known, the name of the minor, his whereabouts, and the character and extent of his injuries. The physician would be reporting authorized information if his report stated the name of the minor, his whereabouts, the character and extent of his injuries, and that the injuries appear to lave been inflicted by other than accidental means. A report which went beyond these statements and labeled the parents as child abusers would not hiterally be authorized by the section..$^{50}$ Under

50 Several states in their reporting statutes have required that the physician also include in the report other information which might be helpful in establishing the cause of the injuries. See, e.g., Colo. Rev. Stat. Avv. \$§ 22-13-1 to 22-13-7 (1963) (any other information which in the opinion of the physician may be holpful in establishing the cause of the child's injury or injuries and the identity of the perpetrator or perpetrators). Coupled 
an approach based on the statutory purpose, such a report might well be authorized.

A second exception to the immunity clause under the literal approach, and probably also under a statutory purpose approach, may occur where no reasonable physician could have suspected that the injuries were inflicted. The scope of this exception depends upon whether a subjective or objective test is adopted. If a physician is required to report when it should have appeared to him that the injuries were inflicted, then arguably a report is not authorized where it should not have appeared to him that the injuries were inflicted. If the more reasonable interpretation of the statute as imposing a subjective test is adopted, then a report would be required and authorized when it did appear to the physician that the injuries were inflicted. A consistent interpretation of the statute would necessitate adopting the same test, either subjective or objective, for purposes of both liability and immunity.

A third exception could be implied for cases involving malice, ${ }^{51}$ but it seems unwise to do so. First, a case might arise where the physician's actual motive for reporting was malicious, yet he may have at the same time believed (or had reasonable grounds to believe) that the case was one of abuse. Reporting would be desirable in such a case regardless of the physician's motive, and immunity should be granted. Second, the exception to the immunity clause, arising from the statutory language, for cases where it did not actually appear to the physician that the child was victim of abuse, serves much the same purpose as an exception for malice. The subjective test would often produce substantially the same results as a malice exception because the elements of proof would probably be the same-knowledge that the statement is false, or lack of either an honest belief in its truth or reasonable grounds for believing it to be true. ${ }^{52}$

It is unlikely that immumity extends to cases involving only mental suffering since section 11161.5 requires reporting only where it appears that the minor has physical injuries. An anomalous situation is thus created in which a physician or surgeon may be required to report, under sections 11160 and 11161, an abuse case involving only mental suffering, yet not be entitled to the immunity afforded by section 11161.5 in

with an inmunity clause, as the Colorado statute is, this language appears to allow the physician great discretion in reporting without fear of legal action against him.

51 The model act proposed by the Children's Bureau of the United States Department of Health, Education and Welfare, reprinted in McCoid, The Battered Child and Other Assaults Upon the Family: Part One, 50 MTNN. L. Rev. 1, 20-21 (1965), protects "anyone participating in good faith in the making of a report pursuant to this Act."

62 See MacLeod v. Tribune Publishing Co., 52 Cal. 2d 536, 552, 343 P.2d 36, 45 (1959) (elements of proof for actual malice). 
cases of physical injury. A similar unfortunate situation exists for those persons required to report under section 11160 , such as hospital managers and ward directors, who may not come within the class of persons required to report under section 11161.5. Unless these people are described in section 11161.5, they are not granted immunity under the statutes even in cases with physical injuries.

Even if a report is found to come within one of the possible exceptions to the immunity clause, a suit against the physician, based on his report, would probably have slight chance of success. Such a suit would proceed on a theory of malicious prosecution or defamation. In a suit for malicious prosecution, the plaintiff would need to prove that the physician, with actual malice ${ }^{53}$ and without probable cause ${ }^{54}$ to believe that his clrarges were true, instituted a criminal proceeding against the plaintiff that terminated in plaintiff's favor. It is unlikely that a physician in reporting a case of suspected child abuse would be considered as having instituted the criminal proceeding. ${ }^{55}$ In addition, the burdens of proving actual malice and lack of probable cause would be considerable.

In a suit for libel or slander, the plaintiff must prove that the alleged defamatory matter referred to him. ${ }^{56} \mathrm{~A}$ report stating only that the plysician believes the injuries were inflicted, without naming the perpetrator, would not seem to satisfy this requirement. Even if the report clearly referred to the parents as probable perpetrators of the child's injuries,

53 Richter v. Neilson, 11 Cal. App. 2d 503, 54 P.2d 54 (1936). The court in Richter held that the plaintiff must establish that defendant was actuated in his conduct by some improper or sinister motive. Id. at $507,54 \mathrm{P} .2 \mathrm{~d}$ at 55 .

54 "Probable cause is a suspicion founded upon circumstances sufficiently strong to warrant a reasonable man in the belief that the charge is true." Centers v. Dollar Markets, 99 Cal. App. 2d 534, 540, 222 P.2d 136, 141 (1950). Medical testimony would probably be necessary to establish lack of probable cause in the case of a physician who reports a suspected case of child abuse, relying upon his medical diagnosis as a basis for his suspicion.

55 The defendant in a malicious prosecution suit need not have signed the criminal complaint to be liable. Bernstein v. Maimes, 126 Cal. App. 2d 468, 272 P.2d 529 (1954); Siffert v. McDowell, 103 Cal. App. 2d 373, 229 P.2d 388 (1951). However, the defendant must have been "actively instrumental" in starting the criminal proceeding or the "proximate cause" of such proceeding. Sandoval v. Southern Cal. Enterprises, Inc., 98 Cal. App. 2d 240, 219 P.2d 928 (1950). Liability has been found where the defendant gave information to prosecuting authorities in such a manner that in the orderly course of police procedure the plaintiff was arrested and a criminal complaint resulted. Id. at 248, 219 P.2d at 934. However, the defendant would not be liable where no action was taken until law enforcement authorities had made a preliminary investigation of the case. Werner v. Hearst Publications, Inc., 65 Cal. App. 2d 667, 151 P.2d 308 (19.44). The latter rule sloould provide protection for physicians reporting suspected child abuse cases.

56 Noral v. Hearst Publications, Inc., 40 Cal. App. 2d 348, 104 P.2d 860 (1940); Vedovi v. Watson \& Taylor, 104 Cal. App. 80, 285 Pac. 418 (1930) and cases cited therein. Califorma Code of Civil Procedure $\$ 460$ provides that the plaintiff in a defamation suit need allege only that the defamatory matter concerned him, but he must establish this fact at trial if the allegation is demed. 
the physician would apparently have a qualified privilege that could be defeated only by a showing of actual malice. ${ }^{57}$ It thus appears that even in cases where the immunity clause of section 11161.5 does not apply, proof of actual malice is necessary.

Despite ambiguities as to both the exact circumstances in which reporting is required and the scope of the immunity clause, the new section 11161.5 is an improvement over the prior statute. Deletion of the clause which apparently gave physicians discretion in deciding when to report ${ }^{58}$ has strengthened the mandatory character of the statute and lessened the serious nature of a conflict with the older general reporting statutes. ${ }^{59}$ The new central registry should prove valuable in detecting cases of child abuse. The existence of an immunity clause will probably allay the fears of physicians about their possible liability for reporting. ${ }^{80}$

III

\section{CRIMINAL PROSECUTION OF CHILD ABUSE CASES}

\section{A. The Pre-1965 California Criminal Statute}

The special California statute applicable to child abuse cases is California Penal Code section 273a. ${ }^{01}$ Section 273a was twice challenged as unconstitutionally vague, but was sustained in People v. Beaugez ${ }^{62}$ and

67 In California the qualified privilege would arise from California Civil Code $\S 47(3)$ which provides that a privileged communication or broadcast is one made "in a communication, without malice, to a person interested therem, (1) by one who is also interested, or (2) by one who stands in such relation to the person interested as to afford a reasonable ground for supposing the motive for the communication innocent, or (3) who is requested by the person interested to give the information." A police officer should qualify as a person "interested" in the comnunication of a report of a suspected crime, and the reporting physician should fall within the classification of subdivision (2). Such an interpretation of California Civil Code $\S 47$ would be consistent with the general common law rule recognizing a qualified privilege that attaches to the report of a suspected crime to law enforcement authorities. See Prosser, TorTs 811 (3d ed. 1964).

68 See text preceding note 42 supra.

60 See text accompanying note 42 supra.

${ }^{60}$ But see McCoid, stipra note 51, at note 95 , where results of a study by the Legal Department of the American Medical Association of the effect of "good Samaritan" statutes, which immunize physicians from civil liability in rendering emergency treatment at the scene of an accident, are summarized. Almost as many doctors were deterred by fear of bability from rendering such aid after the statutes were enacted as before.

61 Prior to its amendment in 1965, California Penal Code $\S 273$ a read: "Any person who willfully causes or permits any child to suffer, or who inflicts thereon unjustifiable physical pain or mental suffering, and whoever, laving the care or custody of any child, canses or permits the life or limb of such child to be endangered, or the health of such child to be injured, and any person who willfully causes or permits such child to be placed in such situation that its life or limb may be endangered, or its health likely to be injured, is punishable by imprisonment in the county jail not exceeding one year, or in the state prison for not less than one year nor more than 10 years."

62232 Cal. App. 2d 650, 43 Cal. Rptr. 28 (1965). 
People v. Harris. ${ }^{63}$ The Beaugez case construed the statute as applying to three types of offenders: (1) the person who willfully inflicts unjustifiable physical pain or mental suffering upon a child or causes or permits him to suffer, (2) the custodian of a child who causes or permits the child's life or timb to be endangered or his health to be injured, and (3) the person who willfully causes or permits a child to be placed in such a position that its hife or limb may be endangered or its health likely to be injured ${ }^{64}$ The court concluded that the third category above, under which the indictment had been brought, was meant to condemn "the intentional placing of a child, or permitting him to be placed, in a situation in which serious physical danger or health hazard to the child is reasonably foreseeable." ${ }^{\prime 15}$

An earlier case, People v. Curtiss, ${ }^{66}$ involved corporal punishment of a child by his teacher. The reasoning of the court did not distinguish that situation from parental child abuse. The first category in Beaugez (willful infliction of unjustifiable pain upon a child) was the only part of the statute at issue in the case. The court construed the phrase "unjustifiable physical pain" to mean pain resulting from punishment which was either improper (the infliction of any punishment at all was wrong) or excessive (although some punishment was proper, the punishment inflicted was excessive in degree). ${ }^{67}$

People v. Harris ${ }^{68}$ is the only other appellate case construing section 273a. As in Beaugez, the indictment was brought under the third category: willfully placing the child in such a situation that its life or limb may be endangered or its health likely to be injured. The court held, contrary to the definition of the third category in Beaugez, that the third category of placing a child in a dangerous situation applied only to custodians of the child. ${ }^{69}$ People v. Harris was not a case of a "battered"

63239 A.C.A. 415,48 Cal. Rptr. 677 (1966).

64232 Cal. App. 2d 650, 656, 43 Cal. Rptr. 28, 32 (1965).

65 Id. at 658,43 Cal. Rptr. at 34.

66116 Cal. App. Dec. Supp. 771, 300 Pac. 801 (App. Dep't of Super. Ct. 1931).

67 Id. at 779, 300 Pac. at 804 . The court followed the majority rule in American jurisdictions. All jurisdictions recognize a privilege of the parent or someone in loco parentis to chastise a child under some circunstances. When the privilege is abused, prosecution may be under general statutory or common law crimes, or under a special child abuse statute. The majority view holds that the privilege does not extend to punishment which is either improper or excessive in degree. A minority of courts hold that any punishment inflicted without malice and causing no permanent injury is privileged. See Annot., 89 A.L.R.2d 396 (1960); Shepherd, The Abused Child and the Law, 22 WASH. \& LEE L. REv. 182, 184-85 (1965).

68239 A.C.A. 415, 48 Cal. Rptr. 677 (1966).

69 Id. at $420-21,48$ Cal. Rptr. at 681. 
child as was Beaugez, but involved living "conditions of filth and wanton neglect which even the most ignorant and insensitive parent should recognize as hazardous to children."${ }^{20}$

There is no appellate case involving an attempted prosecution under the second Beaugez category-the custodian of a child who causes or permits the child's hife or limb to be endangered or his health to be injured. By its terms, the provision did not require that the acts be done "willfully," which in the other two categories was defined in Beaugez as "purposeful" or "with knowledge of consequences." In other words, under Beaugez "willfully" in section 273a meant only a general criminal intent. ${ }^{2}$ This definition of "willfully" left the problem of what state of mind was necessary to constitute an element of the offense in the category not requiring willfulness. Perhaps the negligent causing or permitting a child to be endangered, when done by the child's custodian, would have been sufficient for a conviction. This problem was eliminated by the 1965 amendment to $273 \mathrm{a}$, which included willfulness as an essential element of the crime. ${ }^{73}$

One further problem should be noted with regard to the pre-1965 section 273a. The statute provided that any person guilty of the proscribed conduct could be punished by imprisonment in the county jail not exceeding one year, or in the state prison for one to ten years. Since it was possible that each prosecution might result in a felony conviction, depending upon the sentence, each case had to be handled as a felony. ${ }^{74}$ The procedure in felony cases entails a preliminary examination in municipal court and a trial in superior court, ${ }^{75}$ a cumbersome process when only a misdemeanor sentence is secured.

$70 \mathrm{Id}$. at $420,48 \mathrm{Cal}$. Rptr. at 681 .

71232 Cal. App. 2d 650, 658, 43 Cal. Rptr. 28, 33 (1965). The court construed "willful" in $\$ 273 \mathrm{a}$ as defined in California Penal Code $\S 7$, meaming "a purpose or willingness to commit the act, or make the omission referred to. It does not require any intent to violate law, or to injure another. ..."

72 The court in People v. Beaugez, 232 Cal. App. 2d 650, 658, 43 Cal. Rptr. 28, 33 (1965), indicated that this statute defined a "public welfare" offense, not a "codified common law offense." When the word "willfully" is used in defining the latter type of crime, it requires a guilty mind or intent. When "willfully" is used in defining a public welfare offense, as here, it requires only a general mens rea.

73 Since it was customary practice for district attorneys to charge willful violations of section 273a, the question of what would happen if a prosecution not charging willfulness was attempted did not arise. Interview with Eugene E. Brott, Deputy District Attorney, Alameda County, Califormia, Nov. 17, 1965.

74 Interview with Eugene E. Brott, supra note 73.

75 Ibid. This was the procedure followed in Alameda County, where an information by the district attorney was normally used. [If the defendant pleaded guilty in municipal court, the case was certified to the superior court for sentencing.] Under a grand jury indictment the case would automatically go to superior court. 


\section{B. California Penal Code Section 273a As Amended in 1965}

The new section $273 \mathrm{a}^{78}$ removes the ambiguity which formerly existed as to the state of mind required under the special category relating to custodians of the child who actually endangered him or injured his health, by requiring that the acts be done willfully, thus bringing that category into harmony with the others in the statute. Also, the new statute in subsection (1) provides that if the proscribed acts were done under circumstances hikely to produce great bodily harm or death, the defendant may be subjected to either a felony or a misdemeanor sentence. The proscribed acts are the same as under the old statute, except that in the case applicable only to custodians, there must now be a willful causing or permitting the child to be placed in such situation that its person or health is (not "may be") endangered.

If the proscribed acts were done under circumstances other than those hikely to produce great bodily harm or death, section 273a(2) authorizes conviction for a misdemeanor. The proscribed acts are precisely the same as under section $273 a$ (1) except that those having custody of the child may be convicted for willfully causing or permitting the child to be placed in such situation that its person or health may be endangered. The "is"-"maybe" distinction between 273a(1) and 273a(2) will not be significant in most cases because physical injury will be present, and the case may be brought under another category not involving the distinction. The distinction is probably one of degree, depending upon the probability of harm resulting to the child from placing him in a certain situation. ${ }^{77}$

76 California Penal Code $\$ 273$ a now reads:

(1) Any person who, under circumstances or conditions likely to produce great bodily harn or death, willfully causes or permits any child to suffer, or inflicts thereon unjustifiable physical pain or mental suffering, or having the care or custody of any child, willfully causes or permits the person or health of such child to be injured, or willfully causes or permits such child to be placed in such situation that its person or health is endangered, is punishable by imprisonment in the county jail not exceeding 1 year, or in the state prison for not less than 1 year nor more than 10 years.

(2) Any person who, under circumstances or conditions other than those likely to produce great bodily harm or death, willfully causes or permits any child to suffer, or inflicts thereon unjustifiable physical pain or mental suffering, or having the care or custody of any child, willfully causes or permits the person or health of such child to be injured, or willfully causes or permits such child to be placed in such situation that its person or health may be endangered, is guilty of a misdemeanor.

77 Perhaps the legislature had in mind a distinction involving the necessity of some intervening cause before the child is actually in danger. For example, a child left in a car parked on a hill-top "nıay be" in danger where only a shight force is necessary to send the car careening down the hill. Contrast the case where a parent leaves an infant alone in an unventilated house with the gas stove burners on-this child is in danger. 
Since the same language is employed in the new section 273a, the definitions in People v. Beaugez 78 of "willful" as "purposeful" or "with knowledge of consequences," and in People v. Curtiss" of "unjustifiable physical pain" as resulting froin punishment which is either "improper" or "excessive" should be applicable. The new statute also has apparently made the offense of placing a child in a dangerous situation (the third category in Beaugez) applicable only to custodians of the child. While the old statute was interpreted in People v. Harris ${ }^{80}$ in the same inanner, this construction of the new statute is more clearly correct than the similar construction placed in Harris upon the old statute.

Under both the old and new versions of section 273a, a person could be convicted for "causing or permitting" the child to suffer, or lis health to be injured, or to be placed in a dangerous situation. This provision would appear to partially overcome the problems of prosecuting parents when there are no witnesses to the abuse and each parent protects the other. Assuming it can be shown that the injury was inflicted by someone, then if only one parent was present at the time, the prosecutor can secure a conviction of that parent; if both were present, it is possible under the statute to convict them both, for together they "caused or permitted" the injury to be inflicted. Securing convictions in the latter situation, however, has evidently proved difficult, for juries are reluctant to convict unless the prosecutor can show which parent must have abused the child. ${ }^{81}$

\section{IV}

DEALING WITH CHILD ABUSE CASES:

PRESENT CALIFORNIA METHOD AND POSSIBLE IMPROVEMENTS

The crucial questions in deahing with child abuse cases are what is to be done with these cases and who is going to do it. Three possible ways to handle a case of child abuse are social casework with the family, removal of the child from his parents, and prosecution of the parents.

Since normally the best place for a child is with his parents, the inquiry in each case is whether it is possible to leave the child in his parents' custody, and prevent further abuse by means of casework with the family. An extensive investigation by a trained social worker is neces-

78232 Cal. App. 2d 650, 658, 43 Cal. Rptr. 28, 33 (1965).

79116 Cal. App. Dec. Supp. 771, 779, 300 Pac. 801, 804 (App. Dep't of Super. Ct. 1931).

80239 A.C.A. $415,420-21,48$ Cal. Rptr. at 681.

81 Interview with Eugene E. Brott, supra note 73. In People v. Beaugez, 232 Cal. App. 2d 650, 43 Cal. Rptr. 28 (1965), however, both parents were convicted upon evidence which tended to prove that one of them inflicted the injuries, but did not indicate which parent. 
sary to determine whether casework would be effective. Casework in this area is a long, intensive process requiring specialized knowledge, and is more difficult than casework with parents who do not abuse their children but simply fail to provide for physical or emotional needs of the child. ${ }^{82}$ Nevertheless, social casework does provide an effective means for correcting situations of parental abuse in at least a limited number of cases. ${ }^{83}$

An alternative to social casework is removal of the child from his parents. It is preferable to leave the child with lis parents, but in view of the risk of further injury to the child, in some cases removal, followed by casework with the parents alone, is necessary. Prosecution of the parents is not an alternative which by itself will further the child's welfare, yet it is as appropriate in child abuse cases, where it will not detract from efforts to help the child, as it is in any other criminal case. ${ }^{84}$

\section{A. Existing Procedure of Handling Child Abuse Cases}

The institution primarily responsible in California for handling cases of clild abuse is the juvenile court. When a police officer learns of a case of suspected child abuse, he may investigate and remove the child from the parents' custody if he has reasonable cause to believe the child's home is an unfit place for lim because of the cruelty or neglect of the parents. ${ }^{85}$ If the child is not removed, or is removed temporarily and

82 It is difficult to use social casework techniques in order to bring about changes in the home environment where children are willfully neglected or abused because of the psychological problems of the parents. See text accompanying notes 14-18 infra; National Study Service, Planning for the Plotection and Care of Neglected Children in California, Aug. 1965, p. 103; Report Of INational Agencies Workshor ON Child Protective SERVICES (1957).

83 See generally, De Francis, The Fundamentals of Chend Protection (1955); De Francis, Guidelines for Legislation to Protect tife Battered ChIID (1962); Report Of National Agencies Worighep On Chind Protective Services (1957); Fontana, The Mattreated Cemd: The Maltreatment Syndrome In ChHdren (1964); but see Kempe, Silverman, Droegemueller \& Silver, The Battered-Child Syndrome, 181 J.A.M.A. 17, 20 (1962), remarking that "up to the present time, therapeutic experience with the parents of battered children is minimal. Counseling carried on in social agencies has been far from successful or rewarding. ... At present, there is no safe remedy in the situation except the separation of battered children froin their insufficiently protective parents."

84 Fontana, op. cit. supra note 83 , at 36 , emphasizes that prosecution does not correct the underlying cause of the abuse, and expresses the opinion that fear of prosecution may deter abusing parents from seeking medical aid for their abused child.

85 CAL. WeLfare \& INST'NS Code $\$ \S 600,625$. Section 600 , as relevant here, defines a person as within the jurisdiction of the juvemile court if he is under 21, and his bome is an unfit place because of the cruelty, neglect, or depravity of his parents. Cahifornia Welfare and Institutions Code $\S 584$ gives to every probation officer, assistant probation officer, and deputy probation officer the same powers as a peace officer. 
then released, the police officer may notify the probation officer of the case. If the child is removed and the policeman does not think it wise to release him, the policeman may take him before the probation officer. ${ }^{86}$ From that time on, responsibility for investigating the case and deciding what slould be done belongs to the probation officer. When the minor is being detained, the probation officer must investigate and either hold the child, if it appears that further detention is a matter of urgent necessity, or release lim. ${ }^{87}$ In no event may a minor be detained over fortyeight hours unless a petition to declare him a dependent child of the court has been filed. ${ }^{88}$ If a petition has been filed, a detention hearing before a juvenile court judge or referee must be held before the end of the next judicial day. ${ }^{80}$ The child may be held for fifteen days thereafter if the judge so decides. ${ }^{90}$ The full hearing, to determine if the minor should be declared a dependent child of the court and if so, what is to be done with him, must be held within fifteen days after the detention hearing. ${ }^{91}$

At the full hearing, the court, if it rules that the minor is a dependent child, may order the child placed under the supervision of the probation officer or commit him to the custody of any reputable person, an agency (pubhic or private) equipped to care for such children, or the probation officer temporarily for the limited purpose of boarding him in a suitable home or institution.92 After the minor has been removed, ordered a dependent child of the court, and committed to the custody of a suitable person or institution, juvenile court review is inandatory at least annually to continue the minor's status as a dependent child of the court. ${ }^{93}$

The procedure outhined above is suitable in serious abuse cases where it is imperative to remove the child immediately from his parents' control and commit him indefinitely to another person or institution. It is a course of drastic action whereby the parents unay lose custody of the child at the first investigation by the police, and have the child removed from them indefinitely by means of the petition to juvenile court, detention hearing, and full hearing. Consequently, safeguards exist-such as a

86 CAL. WELFARE \& INST'NS CODE $\$ 626$. When a minor is brought to the probation officer, § 627 provides that immediate steps must be taken to notify the parents.

87 CaI. Wetfare \& Inst'ns Code \& 628.

88 Cax. WetTaRe \& INST'NS CODE $\S 631$.

89 Car. Wetfare \& INST'NS Code $\S 632$.

90 CaI. WELFARE \& INST'NS CODE $\$ 636$.

91 CaI. Welfare \& Inst'ss Code \& 657 .

92 Car. Welfare \& Inst'ns Code \& 727.

93 CaL. Wetfare \& Inst'as Code $\$ 729$. 
right to notice of the detention hearing ${ }^{94}$ and the full hearing ${ }^{95}$ and right to counsel at both hearings. ${ }^{.8}$

The probation officer has alternatives to the process above in handling a case of suspected child abuse. He need not remove or detain a child. He has a general power to investigate whenever he has cause to suspect a case of child abuse. ${ }^{97} \mathrm{He}$ has the power to authorize medical services to a child in an emergency with the parents' consent, when the parents cannot be reached, and over their objection if so ordered by the court. ${ }^{98} \mathrm{He}$ may supervise the minor for six months in heu of filing a petition if the parents consent, ${ }^{99}$ and this provision would seem to authorize social casework with the family as part of such supervision. Consent would probably be readily given in view of the probation officer's power to file a petition if consent is withheld. In a comparatively small number of cases probation departments are now supervising families in which children are living who have been neglected or mistreated.100 If removal is necessary, and the child is committed back to the probation officer, he can handle the placement and supervision of the child or may delegate responsibihity for this to the county welfare departments. The rules governing probation departments and juvenile courts appear to provide sufficient flexibility and authority to effectively handle cases of child abuse.

\section{B. Suggestions For Improvement}

The juvenile court and probation department proceedings are especially appropriate for the particularly serious cases of abuse. They can also be used to provide social casework to prevent further abuse where this is feasible. It is recommended, however, that primary responsibility for child abuse cases be tentatively placed with a special unit in county welfare departments in a few pilot counties. ${ }^{101}$

94 CAL. Welfare \& INST'Ns CODE $§ 630$.

95 CAL. Welfare \& INST'NS COJNE § 658.

${ }^{96}$ Cac. Welfare \& Inst'ss Code $\S 633$ (detention hearing); CaL. Wermare \& Inst'vs CoDE $\$ 679$ (full hearing).

97 Section 652 says the probation officer "shall immediately make such investigation as he deems necessary" to determine if proceedings in juvenile court should be commenced. The "as he deems necessary" language vests in the probation officer discretion in investigating or not; if he does not investigate it is presumed he was exercising his discretion. In re Petersen, 56 Cal. App. 2d 791, 133 P.2d 831 (1943).

98 CaL. WeLFARE \& INST'NS CODE $\$ 640$.

99 CAL. WetFare \& INST'Ns CODE $\S 654$.

100 National Study Service, Planning for the Protection and Care of Neglected Children in California, Aug. 1965, p. 140.

101 Except for the limitation to a small number of pilot counties, this is also the recommendation of the final report of the study by National Study Service, supra note 100, at 139-142. National Study Service is jointly sponsored by the Child Welfare League of America, the Family Service Association of America, the National Council on Crime and 
This recommendation is based upon two separate objections to the existing system. One objection relates to the problem of early discovery of abuse cases; the second (and major) objection is based upon the imappropriateness of the probation department as the primary agency in handling these cases. Early discovery of cases of child abuse is essential. Willful abuse of children not only often results in serious injury or death, but is generally repetitive in nature, so that early discovery and the intervention of public authority are crucial to the clild's pliysical safety. Reports of suspected child abuse cases come from many sources-relatives, neiglibors, scloools, and physicians. Many persons are reluctant to report a matter to an agency connected in their minds with the courts and law enforcement. If social welfare agencies had primary responsibility for abuse cases, these people miglit be more inclined to report situations where they suspect a child is bemg abused..$^{102}$

The major reason for shifting responsibility to welfare agencies stems from the basic nature of the two departments. Probation departments are oriented toward cases of delinquent rather than dependent clildren. They are already burdened with an overload of dehnquency cases. ${ }^{103}$ If the amendment to the mandatory reporting statute results in increased reporting of child abuse cases, then probation departments would be greatly overburdened. The public generally does not distinguish the cases of dependent as opposed to delinquent children who are under the care of probation departments, ${ }^{104}$ and this may have unfortunate consequences for the child's reputation.

Delinquency, and the National Travelers Aid Association. The study resulted from a request by the Governor to the State Social Welfare Board and the Califorma Delinquency Prevention Commission that services for care of neglected children be reviewed. These two bodies established the Joint Study Committee on Children's Services, which employed National Study Service to conduct this study. Califormia Assembly Bill 1914, based upon the preliminary report of National Study Service and defeated in the 1965 session, provided for the establishment of special units in county welfare departments or other suitable county agencies to provide these services to children. This was to be a pilot project in 5 to 10 counties. California Assembly Bill 277, fron which the amendment to California Penal Code \$ 11161.5 emerged, originally required that physicians report to county social welfare agencies. This provision was based upon the theory that these agencies were appropriate to investigate and decide whether social casework or renıoval by means of the juvenile court was needed. Other states have followed this theory. The New York reporting law, for instance, provides for mandatory reporting by physicians and hospitals of suspected cases of child abuse to a society for the prevention of cruelty to children, another duly authorized child protective agency, or to a public welfare official. N.Y. PEN. LAw \$ 483-d. California Penal Code $\$ 11161.5$, prior to its amendment in 1965, allowed the physician to report, in his discretion, to either law enforcement authorities or to the nearest child welfare agency offering child protective services. The present statute requires reporting to the head of the police department, the sheriff, or the district attorney.

102 National Study Service, supra note 100 , at 140.

103 Id. at 141.

104 Id. at 141; see also Gardner, The Juvenile Court, 40 CAL. S.B.J. 349, 349-50 (1965). 
Social welfare departments inherently are the appropriate agency to engage in this type of work; they are already working with the similar situations of neglect and deprivation. It makes better sense to shift the responsibility for cases in which it is anticipated that social casework will be needed to an agency skilled at that work, than to load an already overburdened agency-the probation department-with cases that are outside the range of its primary orientation.

The proposal is simply that welfare departments make an initial investigation and provide social casework if that appears appropriate. Police and probation officers would still have authority to immediately remove children in danger, as now provided by law. Social welfare personnel could work with the probation department where removal is necessary. Any removal (with the exception of temporary detentions) ${ }^{105}$ and directions for subsequent care would be done by order of the juvenile court. Existing law already provides that a dependent child of the court may be committed to the care of public social agencies. ${ }^{100}$ Such a direct commitment seems more desirable than the present commitment to the probation department followed by a delegation of responsibility for placing the child to social welfare agencies as is done now in many counties. ${ }^{107}$ This change would not detract from the power of district attorneys to prosecute the parents, but cooperation with the welfare department would be essential in order to minimize interference with the casework process.

It seems unwise to introduce a wholesale shift in responsibility for child abuse cases from probation departments to social welfare agencies throughout the state until the factual assumptions supporting such a shift are more clearly proven correct. It is not certain that increased reporting will result if welfare agencies are given primary responsibility, nor is it clear whether a large number of serious abuse cases will be amenable to social casework. Any large-scale change in function of welfare agencies and probation departments should be postponed until it is shown that benefits resulting from a shift in a few pilot counties justify such a change.

\section{CONCLUSION}

Although the precise requirements of the California reporting statutes are not clear, the recognition of a legal obligation on the part of physi-

105 CAT. WeLFARE \& INST'NS CODE $\$ \S 584,600$, and 625 give police officers and certain probation officials power to temporarily detain a child if they have reasonable cause to beheve the child's home is an unfit place for him because of the cruelty or neglect of the parents. See note 85 , supra, and accompanying text.

108 Cas. Welfare \& Inst'ns Code $\& 727$ (d).

107 National Study Service, supra note 100, at 151-152. 
cians, to report cases of suspected child abuse, expressed in a statute specifically applying only to child abuse cases, should result in a greater awareness by physicians of their responsibilities in this field. The recent amendment to the California criminal statute pertaining to child abuse has both clarified its substantive prohibitions and provided more flexible procedures under which to prosecute abuse cases. However, experimentation with social casework in the field of child abuse is needed, and it is hoped that legislative programs under which such social casework can be utilized will be forthcoming. 